Article

\title{
Methodological Perspectives on British Commercial Telegraphy and the Colonial Struggle over Democratic Connections in Gibraltar, 1914-1941
}

\author{
Bryce Peake \\ Media and Communication Studies Department, University of Maryland, Baltimore, MD 21250, USA; \\ E-Mail: bpeake@umbc.edu
}

Submitted: 29 September 2017 | Accepted: 24 November 2017 | Published: 9 February 2018

\begin{abstract}
This article examines the privatization of telegraphy in the British Empire from the perspective of Gibraltar, an overseas territory in the Mediterranean. While the history of international telegraphy is typically written from a world-systems perspective, this article presents a key methodological critique of the use of collections spread across many institutions and colonies: archival satellites are not simply reducible to parts of a scattered whole, as archival collections are themselves curations of socially-positioned understandings of Empire. This is especially true of the "girdle round the world" that was British telegraphy. At a meta-historical level, individual archival collections of the global British telegraphy system can be read as histories of colonial administrators' geographically- and socially- situated perspectives on Empire-namely through what archives have, and have not, preserved. I demonstrate how the documents about telegraphy collected and maintained in the Gibraltar National Archives reflect pre- and post-World War I English, anti-Liberal colonial administrators' and military officials' fear that privatization was an opening salvo against the democratic web that held the last vestiges of Empire together.
\end{abstract}

\section{Keywords}

British Empire; colonial management; historical methodology; media archives; media history; telegraphy

Issue

This article is part of the issue "Media History and Democracy", edited by David W. Park (Lake Forest College, USA).

(C) 2018 by the author; licensee Cogitatio (Lisbon, Portugal). This article is licensed under a Creative Commons Attribution 4.0 International License (CC BY).

\section{Introduction}

In 1933, Cable and Wireless LTD began what was a tumultuous cohabitation with the British postal service in Gibraltar. The telegraphy company was initially forced to conform to the reduced hours, limited housekeeping, and staffing sacrifices required of the Main Street Postal Office amidst the post-World War I austerity measures. Heated exchanges regarding democracy and public interest ensued between the colonial postmaster H. G. Jessop and L. C. Hopecraft, the manager of Cable and Wireless, LTD. Despite Jessop's rhetorical victories in the names of honor, glory and public interest for Gibraltar, however, the private economic interests of the Cable and Wireless, entangled as they were with the political interests of politicians in the UK, gained the economic high-ground. The immediate result: a grille funded by the local government (Figure 1) to block off the postal office, allowing Ca- ble and Wireless to remain open in a government-funded building - while the government service was forced close by post-war austerity measures. Eventually, the Postal Office was nearly expelled completely from its own building, and a significant amount of funding was redirected to Cable and Wireless, LTD.

Telegraphy in Gibraltar became a primary means for military communication in the years preceding World War I, replacing postal carrier and carrier pigeon as the most secure and efficient way of moving intelligence throughout the British Empire. Gibraltar, importantly, served as the node through which the Eastern and Southern empire was connected to the metropole via the Indian cable (a line that ran from Falmouth to Malta to Egypt, operated by one of Pender's many international cartel operations). Following the war, telegraphy began to take on a more commercial role by communicating to private ships; while the military owned the infrastruc- 


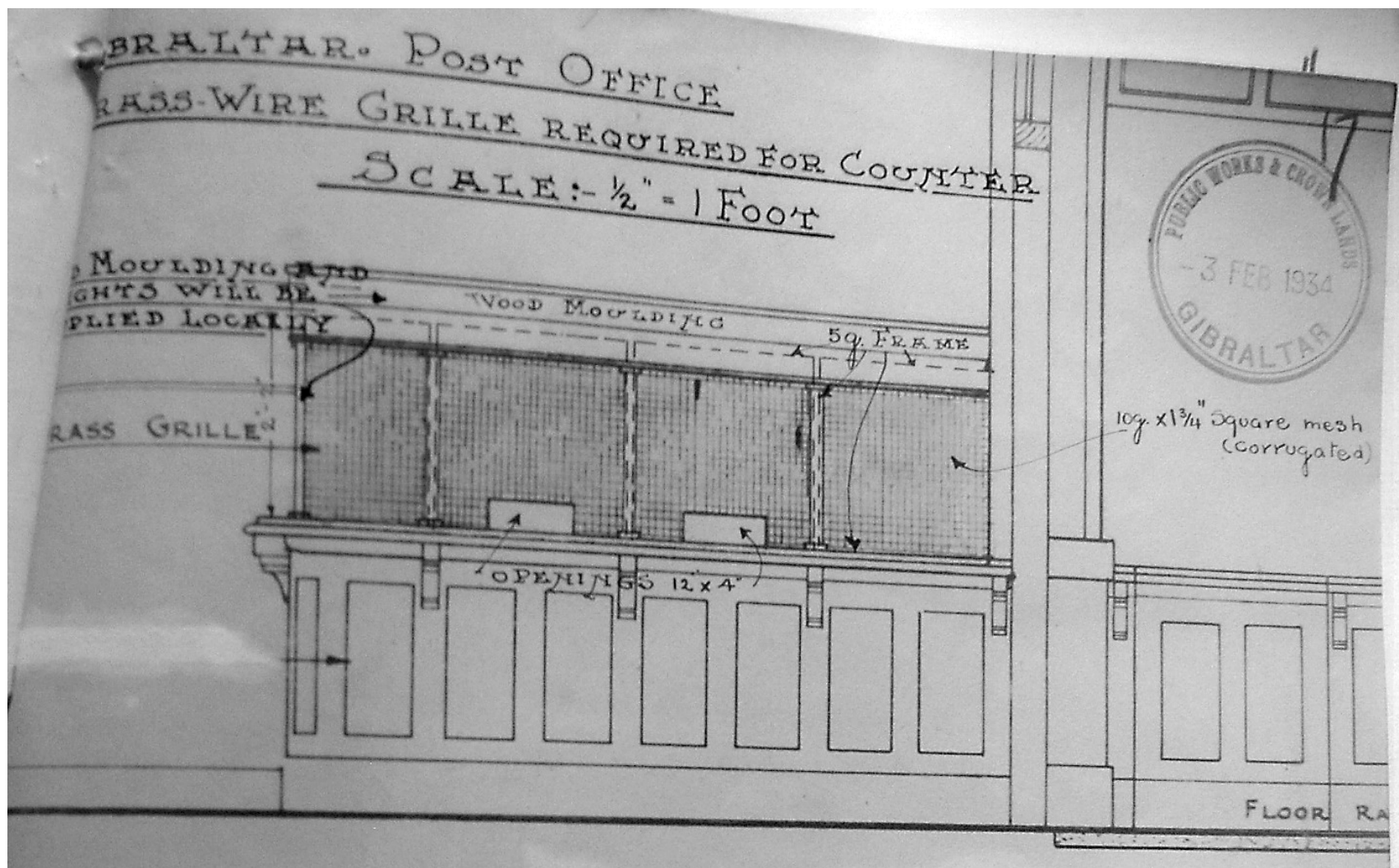

Figure 1. Gibraltar post office brass-wire grille schematics, 3 February 1954.

ture of telegraphic communication, the colonial state and entrepreneurs sent messages through a commercial service, then called The Eastern Telegraph Limited, closely monitored by British Intelligence. Between the years of 1914 and 1944, this commercial service had cycled through 10 different names, at least 20 different heads and leaders, each of whom were called any number of titles-first superintendent, then director, then manager, indicative of telegraphy's transformation from state, to public, to corporate entity.

This article examines the historical implications of privatized telegraphy on Commonwealth postal service in the British Mediterranean from the perspective of Gibraltar, an overseas territory that precipitated the cannibalization of public services thought to be core to democracy (to the English colonial administrators who ran it) in the name of "recovery" after World War II. I argue that telegraphy was the locus of a post-World War I struggle between British aristocrats, Gibraltarian merchants, and English liberals, which marked an economic transition that reverberates into the contemporary moment. This claim comes by way of a secondary methodological argument: in general, archives are not capable of creating a "global" historical account of any communication institution, let alone as it regards telegraphy. Using historical anthropological approaches to archives that contextualize the practice of archiving, this article demonstrates how Gibraltar's collection of archival documents give not only a history of telegraphy, but a story about Gibraltar's colonial administration's percep- tion of and perspective on the relationship between colonial administration, class hierarchy, colonial legitimacy, and communication capitalism. Historians, then, must engage in a meta-historical practice as well: documents were institutionalized by Gibraltar's officials in order to curate a narrative about privatization as an incursion on the democratic web that held the last vestiges of Empire together.

\section{The Telegraphic History of Archiving Telegraphy}

Gibraltar is a small 2.5 sq. mi. territory located on the Iberian Peninsula that became a British Crown Territory in 1713 by the Treaty of Utrecht, and remains a British overseas territory today. Gibraltar was an asset to the British principally for controlling access to the Mediterranean. In 1727, considering various European conflicts (e.g., the War of Austrian Succession, the Anglo-Mysore Wars, the coming Napoleonic Wars) Gibraltar was refortified and re-weaponized as a necessary asset to the British War Department. Repairs of similar scale were not undertaken again until just prior to World War I. By that time, an immigrant civilian population had also taken up residence in Gibraltar. Two bodies governed this group of individuals: the colonial administration (principally a governor and colonial secretary appointed by and from the Royal Army, charged with ruling citizens on the King's behalf) and the Admiralty (typically a senior Naval commander charged with control over military operations and personnel, answering to the secretary of state of 
the colonies). ${ }^{1}$ In addition to modernizing the armament, garrison, and weaponry in 1907, these two governing bodies initiated the widespread installation of electricity in military establishments, including those commercial civilian establishments where military personnel ate and drank. Alongside this, commercial telegraphy was officially institutionalized on the peninsula, plugging Gibraltar into the commercial "girdle round the world" (BartyKing, 1980; see also Winseck \& Pike, 2007).

Through the commercialization of the girdle, class hierarchies were carved into the colonies connected by telecommunications infrastructure. As Bernard Porter (2006) remarks, the post-World War I empire was a zone of conflict between an emerging capitalist class and descendants of the historically-grounded aristocracy, itself constantly in struggle over who was "truly" English. While the aristocracy was believed to have "stayed at home" to govern in cabinet positions, its lowest-valued members were typically sent throughout the Mediterranean colonies in service of those offices, or as military commanders without military power-creating a community of resistance to liberalism that strategized around, among other institutions, telegraphy. As the dwindling aristocracy stepped away from ruling empire, they devoted energy to training the upper middle class, themselves aspirationally, if not previously consanguineously, aristocratic, to run the empire from an aristocratic epistemology that centered moral duty in Empire. To the aristocracy, this small group of the upper middle class "made the best colonial administrators precisely because they could rise above the sordid motives that were attributed to the commercial bourgeoisie" (Porter, 2006, p. 61). The petty aristocracy and upper middle class officials in places like Gibraltar, regardless of pedigree or education, were viewed as incompetent figureheads at best, there simply to sign colonial directives pushed by their more established and successful kinsmen at home. ${ }^{2}$ Confident of their place in society, by the end of World War I the aristocratic cabinet ministers at home came to happily collaborate with capitalists abroad, alienating the lower aristocratic and upper-middle class outcasts who continued to be committed to Empire as a service to the world by the State. The history of telegraphy in Gibraltar, then, is a story about capitalism's attempts to replace "old" money imperialism with globalized business to build Great Britain's next age of greatness.

Just as the history of telegraphy in Gibraltar is grounded in a complex class politics, so too does the archival preservation of telegraphy history reflect this struggle. Anthropologist Nicholas Dirks has argued that archives are "that primary site of state monumentality...the very institution that canonized, crystallized, and classified the knowledge required by the state even as it made this knowledge available for subsequent generations in the cultural form of a neutral repository of the past" (Dirks, 2002, p. 61). As admiralty, colonial governors, and capitalists fought over telecommunications ownership, so too did they fight over how telegraphy would be represented in the metropolitan monument to the British Empire. The narrative about telegraphy contained in the National Archive, then, is more a narrative composed about the political struggles of state imaginaries in the core than telegraphy as it ran throughout the peripheries.

Yet, Great Britain's smaller State archives, such as that in Gibraltar, which continue to escape any oversight from archival authorities, could institutionalize local administrators' perceptions of how telegraphy was stolen from Gibraltar at the twilight of aristocratic rule. Although "the colonial archive was not just the record of the colonial state but also the repository of the sources for an imperial history whose public was the metropole rather than the colony" (Dirks, 2002, p. 63), Gibraltar's archives tell a story of a colony where its administrators felt "shut out" from the process of deciding the best directions for Empire. More directly, then, while documents may hold content about telegraphy, the pragmatics of their archiving (and the decision not to archive certain materials) Gibraltar's colonial administrators' perceived slight against their ruling birthright; a slight that was facilitated by the domestic aristocracy's collusion with liberal internationalism. In short, the history of telegraphy according to Gibraltar (the narrative that a state tells about infrastructure and colonialism) is an utterance separate from, and frequently contradicting, the history captured by collections at the National Archives.

This marks a methodological problem relatively unaddressed in media history. While historians scour multiple archives to piece together histories from documents scattered around the world, they often forget that these documents are not so much part of a global whole as they are the materialization qua preservation of local colonial histories from grounded and conflicting perspectives on telegraphy's promise and place in imperial state-making. This is a problem at a disciplinary level, as well. Media history as a practice was grounded in the professional archiving of corporate media entities, where institutional historians focused on the storing and sometimes preservation of materials - not what the keeping of those materials necessarily meant (Startt \& Sloan, 1989). The dominant positivist paradigm of classical historicism (which dominated lay and administrative archiving) largely ignored the various turns of historiographic debates, from Marxist Historicism to French Annales to Italian Microhistory to the American and French Linguistic turn (to name just a few). And, without historians to bring these

\footnotetext{
1 There is a terminological problem here: The secretary of state of the colonies is sometimes given in shorthand as the colonial secretary. In Gibraltar, colonial secretary is the name of the position called Lieutenant Governor in other spaces. In this paper, I use the full title for the secretary of state, and colonial secretary for the local lieutenant governor.

${ }^{2}$ While Empire provided an upwardly aspirational middle and artisanal class with forms of education that would lead to prestige-generating jobs, it was supervised by the lower rungs of the aristocracy (whether aristocratic proper or upper middle-class proxies), whose higher achieving kinsmen and peers remained at home to direct the empire from afar.
} 
perspectives into the field of media and communication studies, subfields like cultural/critical media studies and media sociology have largely ignored debates about the nature and social production of historical time and artifacts.

In what follows, my argument is not that there is one undisputable history of telegraphy that we have access to via primary sources contained at either archive. Rather, I simply demonstrate the history preserved in the selected archiving of documents in Gibraltar, and argue that this collection reflects more about the struggles of administrators than an objective and true history. In other words, the history of telegraphy contained in the Gibraltar archives preserve a struggle over the communication infrastructure necessary for modern statemaking. As becomes clear, the Gibraltar Archives represent the voices of an oft forgotten resistance to the privatization of public communication infrastructure, namely that of an anti-Liberal military and civilian colonial aristocracy doing the work of (and not simply legislating) making empire.

\section{Democracy and Telegraphy in Gibraltar}

Wireless telegraphy (W. T.) in Gibraltar was originally the property and service of the military. ${ }^{3}$ In 1904, regulation of telegraphy fell under the Summary Conviction Ordinance of 1885, sections 37-40, "Carrier Pigeons and Wireless Telegraphy Apparatus" (Gibraltar Archival Document, 1922b). Under this legislation, all long-distance transmissions in fortifications were strictly under the control of the British military: the messaging apparatus, the service provided, and the employees who received and sent messages fell under control of the Colonial Post Master, who reported directly to the Admiralty and Colonial Governor in Gibraltar. This norm, established while the War and Colonial Department (1801-1854) oversaw the colonies and dependencies, remained in place when the supervision of colonial governors was transferred to the colonial office (1854-1966). Under various schemes, telegraphy became a mixed private-public endeavor on occasion, until World War I.

On the heels of the World War I Defence of the Realm Act (DORA) in September 1914, which gave the military total control over any publicly- or privately-owned infrastructure that would aid in the war effort, the British Admiralty claimed total control over inbound and outbound communications. As a colony where the fortress came first (Finlayson, 1996), the Great War had required so much labor and communication time that any commercial service was completely disregarded by December 1914. To mediate the effects of total military control over telegraphy, the Colonial Governor's office proposed that a secondary station, the "Windmill Hill telegraphy station", be completely leased to the Colonial Government, who would in turn allow Eastern Telegraph Company to use the facilities for commercial service-the Eastern Telegraph Company had always used colonial and military infrastructure to provide their service in Gibraltar, and thus existed only insofar as the British state allowed it to (Gibraltar Archival Document, 1914).

The secretary of state of the colonies, siding with the Admiralty, refused this proposal for a private, commercial service twice, first in December 1914 and then revising his stance (but not his decision) in May 1915.

The first refusal was on the grounds that "Owing to possibly closing for Naval purpose and shortage of operators, Windmill Hill W. T. Station cannot be placed at disposal of colonial government at present" (Gibraltar Archival Document, 1914). While "naval use" remains ambiguous in the archival documents, the admiralty is clearly concerned with labor. A well-paying commercial service might have seized the most qualified telegraph operators in Gibraltar from the military, or rendered conscripted operators resentful. Other documents argue that a commercial station could also attract spies intending to use the privatized equipment to undermine British control.

The secretary of state's second refusal came between January and May 1915, only recorded in a précis of communication exchanges regarding telegraphy written by the colonial secretary in 1930 (Gibraltar Archival Document, 1930b). According to this précis, the admiralty believed the commercial station would also cause "interference" with the military W. T. stations. However, a change in admiralty leadership later in 1915 created the potential for changes in telegraphy station ownership. The new Senior Naval Officer (SNO) Admiral Borck was "informed of arrangements contemplated and a review of the situation given to him: his opinion requested on the subject, particularly as regards "interference" from other stations in vicinity". By June 1915, however, the commercial proposal was abandoned both by the Eastern Telegraphy Company, who had been conversing with Marconi Wireless Telegraphy Company about gutting older public buildings and infusing them with the new Marconi technology. The reason for their abandonment of this issue, according to the colonial secretary and governor, is "owing to impossibility of non-interference with Naval W. T. work". Admiral Borck responded that this was for the best, as Gibraltar's primary telegraphy station, Europa Station, could not possibly monitor and censor commercial messages in addition to other naval duties in the future: "the working of more than one wave-length by one station being unsuitable" (Gibraltar Archival Document, 1915a).

Eastern Telegraphy Company's abandonment of the use of state infrastructure occurred against the property laws of wartime Great Britain. In 1915, DORA meant that all forms of infrastructure, especially state-subsidized infrastructure, could be coopted by the military, which would result in heavy business losses for the Eastern

\footnotetext{
3 Telegraph was originally privatized in Great Britain, which came to an end in 1870 in the UK. However, given Gibraltar's primary function as a military base, and not a colony proper (i.e. an imperial relationship), the infrastructure had always belonged to the State.
} 
Telegraphy Company. The enlistment of Marconi by Eastern Telegraph Company suggested that the company was considering a makeover of the then current technology, to increase the efficiency, and thus profit, of telegraphy. However, had the Eastern Telegraph Company become more powerful in communication than the state itself, their W. T. station would have become a prime target for military seizure under DORA. As stated in Clause B of Section 1 of DORA, the Majesty in Council, or any military member acting on his behalf, would take any means necessary to "secure the safety of any means of communication" (DORA, 1914). In short, Eastern Telegraphy Company abandoned their pursuit of a telegraph station because they refused to build new communications infrastructure for inevitable military seizure.

Despite the Eastern Telegraph Company's abandonment of the project, the colonial secretary pressed on with the need for a commercial wireless station. In October 1915, he requested the admiralty consult and obtain an expert opinion on the question of employing multiple wavelengths from a station. Additionally, to sweeten the deal for the admiralty, he stated in his message to Admiral Borck that the citizens and government would subsidize the military's use (and monitoring) of the Eastern Telegraphy Company's new Marconi technology (Gibraltar Archival Document, 1915b).

Privatization, according to the colonial secretary, would lessen the military's financial burden of providing communication infrastructure for itself and surrounding civilian labor force. Going one step further, the Governor suggested that the "Admiralty's responsibility should be extended to financial control and that any expenditure involved should be defrayed from Admiralty Votes, the interests of the Admiralty and Colonial Government not being regarded as divergent" (Gibraltar Archival Document, 1915b). In a follow-up letter to the secretary of state of the colonies from the Admiralty dated December 1915, the Admiralty notes that the issue of multiple wavelengths had not been considered-perhaps because it was a fabricated non-issue-and that the use of Windmill Hill station by the Colonial Government is "anticipated to provide a service more efficient than could be obtained through any private company" (Gibraltar Archival Document, 1915c). In January 1916, the station was reopened by the Admiralty for limited, well-monitored and often censored, private and commercial purposes. However, by August 1917, the Admiralty closed the station, greatly reducing commercial service to government needs only until well after the war (Gibraltar Archival Document, n.d.).

In July 1922, four years after World War I and the fear of the DORA, the colonial government made a significant pivot in its own position regarding privatization. The Admiralty proposed constructing a new $\mathrm{W}$. T. station at the South of Rock Battery, abandoning the North Front Station. As the Admiralty wrote in a telegraph to the secretary of state of the colonies, "Enquiry whether Colonial Government would be prepared to make an offer for the present W. T. Station and to operate it for commercial purposes" (Gibraltar Archival Document, 1922a). Contacted assumedly by the secretary of state, the colonial secretary responded as such on 6 October 1922:

I have the honour to state that I consider the maintenance of a wireless station here, available for commercial purposes, to be of considerable importance to the mercantile community. At the same time, I should hesitate to make an offer on the part of the Colonial Government for the purchase of the present Rock Wireless Telegraph station with a view to operating it as a commercial station since Government methods do not, generally speaking, lend themselves to commercial enterprises of this kind, nor has Government the expert knowledge required to make it a success. I would therefore suggest that the Eastern Telegraph Company might be approached with a view to ascertaining whether they would make an offer to purchase and operate the Admiralty's Wireless Station. If however the Company is unwilling to do so on reasonable terms, I should be prepared to consider making an offer on the part of the Colonial Government, as a commercial Wireless Station here would certainly be of benefit to the trade of the port, and if properly managed, should pay its way. (Gibraltar Archival Document, 1922c)

No longer interested in state run infrastructure with private service, the colonial administration argued for state-facilitated private investment in the entirety of communications-a clear, early example of the State's divestment of nationalized infrastructure. Either the Eastern Telegraph Company would buy the telegraph company, and the entire system would be privatized, or the colonial administration would buy it, and as stated in a private communication dated 12 October 1922, would "make considerable concessions" (i.e., hand it over) to the Eastern Telegraph Company, because it would prove "of benefit to both merchant and citizen" (Gibraltar Archival Document, 1922d).

The war office agreed with hesitation. By the end of September 1924, The Committee for Imperial Defense noted that communication stations have become a necessary part of the British military complex, but that they have also come to be expensive to maintain during times of peace. In a circular, the Committee states:

It is clear that the cost of, and time required, to recondition stations that have not been kept in good order by continuous work makes it most unwise to allow stations that will be required in war to drop out of use. Nor should important Dominions and colonies be isolated and dependent solely on cable communication at critical periods. It is therefore important to have the largest possible number of W/T stations in operation in peace time consistent with economy. To meet the interest on capital charges and the cost of 
maintenance it is desirable to get what assistance is possible from commercial work, as is done on a small scale today in Gibraltar, Aden and Bermuda Dockyard, as well as at all stations operated by the Dominion and Colonial governments. (Gibraltar Archival Document, 1924)

By the Committee's logic, if W. T. stations went unused, they would become worn down and thus useless for the next war- "the next war" being a popular theme in British military rhetoric and history (Robbins, 1996). But the logic here is inherently capitalist. Depreciating machinery at rest directly reduces the potential for capital, noting that the industrial slump and degradation of factory production capacities were one of the principle drives of World War I in Gibraltar and Great Britain (Caruana, Rockoff, \& National Bureau of Economic Research, 2006). If left unused, the telegraphy machinery would neither be able to repay its cost, nor generate the surplus needed for maintenance before going obsolete. Thus, the logic at work here is that it was better to privatize the telegraphy machinery and receive some return on investment than for the state to become "a prisoner of his investment" (Landes, 1969). And so, it was reasoned that the state should find ways for private groups to manage telegraphy during peacetime-a pivotal moment in the privatization of nationalized infrastructureand that the admiralty could hypothetically re-seize the means of communication in Gibraltar in future war efforts with minimal investment. Notably, the admiralty would continue to control and maintain the cable lines in and out of Gibraltar, but colonial government would leave the telegraphy business.

As a result, the Eastern Telegraph Company controlled all telegraphy service, save for communication between the Admiralty, Colonial Government, and British State. Their demands on the military, as the owner of the infrastructure, had become quite costly. However, Eastern Telegraph Company's heavy use of the infrastructure, and their constant needs for repair, was far less than the cost the Empire would endure to replace outdated and depreciated machinery in the event of another war. Where the state hoped to privatize the communication infrastructure with the intent of simply reappropriating it for the next armed conflict, at little cost to the state, Eastern Telegraphy Company refused to purchase the outmoded infrastructure. Instead, they relied on the state to technologically facilitate their constant attempts to generate profit.

As a colony tasked with connecting the whole of the Eastern and Southern British Empire through W. T., Gibraltar was thrust into the international-turningglobal telecommunications infrastructure. However, the metropole-run telegraphy service was not simply a part of a network of global communication, but simultaneously a competitor. In 1925, a letter from the Post Master General to the Post Master of Gibraltar states that the State-owned transatlantic message cables were not receiving any commercial traffic from the colonies, "despite connecting Great Britain with the rest of the world more or less. In many countries, the Imperial cable service does not even appear on maps and message routes" (Gibraltar Archival Document, 1925). In Gibraltar, civilians and military personnel alike were drawn to the cheaper and more reliable commercial service being offered by private companies in Spain. This cost the British W. T. companies considerable money, as official government use of the transatlantic line was free in exchange for friendly regulations of commercial W. T. ventures. This telecommunication-oriented connection to the world, however, is not simply a participating in a global network, but the insertion into a global communications regime.

In 1927, both the British state and various British private commercial enterprises took part in the Washington International Radiotelegraph Convention-the first convention in which International Radiotelegraph and Telegraph Conventions were fused. 80 countries and 52 private companies sent representatives to the convention, making it the largest since the formation of both original conventions.

While there were numerous treaty articles with substantial impact on the way telegraphy was operated globally, the most substantial article was one that dictated the grounds of participating in the international wireless community, entitled "Article 7: Connexion with the General Communications System". In this article, as it was interpreted by the British secretary of state of the colonies in a letter to the colonial secretary and admiralty in September 1929, colonies would no longer be allowed to participate in international radiotelegraph telecommunications under the banner of their mother country; Gibraltar would no longer be represented by, and afforded access through, Great Britain (Gibraltar Archival Document, 1929b). This left colonies like Gibraltar with two options: either pay an undisclosed sum of money to become a participating country-an amount well outside the means of Gibraltar according to a response from the colonial secretary; or, should these countries wish to remain connected, they would be required to contract all of their commercial telecommunications needs to a private company that held a position in the organization, all of which were part of a mutually beneficial cartel (Winseck \& Pike, 2007). Even if these colonies bought into the system, they would still be denied a vote; instead, their voting would be represented by the one voted allotted to their respective metropole. This regulation, it appears in the proceedings of the conference, were done in fear that Britain would strong-arm its colonies into voting to Great Britain's benefit (and the possible loss of other countries lacking the colonial influence of the Empire). Gibraltar would pay large sums of money, but would yet be denied any form of independent participation (Gibraltar Archival Document, 1930a).

All those colonies of the British, French, German, Spanish, Dutch and Portuguese who did not have the 
monetary means to participate as a state would have their infrastructure sold-by the metropole, no less-to a private company. Such was the case in Gibraltar, where the privatization of telecommunications infrastructure was an articulation of the need to participate in the global economy and the crumbling British Empire. Recovering from World War I, Britain began struggling to maintain the capital to both refurbish its Royal Navy and fund colonial administration (Broadberry \& Harrison, 2009). In 1934, seven years following Article 19 the Admiralty in Gibraltar responded that it would not pay into this system. "We are part of the United Kingdom of Great Britain, allotted one vote and thus willing only to pay once" (Gibraltar Archival Document, 1934c). The Admiralty, with its aristocratic officers, would fold neither to the "lesser" aristocrats put in charge of colonial management at home or abroad, nor to the Liberals with no claim to title.

However, the Admiralty's protest had come years too late: the government-controlled commercial service had been sold by the metropole and incorporated in 1929 in order to meet the interpretations of the convention, among other reasons. A letter from the secretary of state of the colonies to the colonial secretary in August 1929 states:

That the arrangements for the fusion of the Principal British cable and wireless interests and the transfer to the Company so formed of the greater part of the governmental activities of this kind in the United Kingdom have now been completed. The merger company (Cables and Wireless Limited) and the communications company (Imperial and International Communications Limited) were formally incorporated on the $8^{\text {th }}$ of April last and the Agreement between the Companies and the Governments concerned was signed on the 29th of May 1929. (Gibraltar Archival Document, 1929c)

The Admiralty would still control the government-owned and operated service, as well as have the power to overtake the commercial system in times of war would it have been necessary-as would be the case in smaller colonies like that of Gibraltar and the Falkland Islands. Commercial interests, however, now belonged purely to Cable and Wireless LTD, including national communiques:

They will at all times during the continuance of this Agreement maintain an efficient and regular communications service between all those parts and places in the British Empire heretofore served by the vari- ous communications services to be acquired by them and will not without the consent of the Advisory Committee sell, lease, charge, or otherwise dispose of any property rights or assets of the Company for the time being used for the purposes of communication between the parts and places aforesaid otherwise than in the ordinary course of administration or management or for the purpose of replacing worn-out, disused, or obsolete plant. (Gibraltar Archival Document, 1929a)

Great Britain, again according to the story told by this one archive, had decided that, to best control its communications interests, it would sell the telegraphic infrastructure that connected all of its colonies to a British company, lest the colony be exploited by some other national entity other than the British. ${ }^{4}$ The decision was such: As part of a British private holding, the telegraphic industry would pay taxes and be under the control of the British government; otherwise, as independent countries exercising their rights in the international convention, the colonies would command more power against the metropole. Further, the metropole would maintain some "control" over the privatized company by providing subsidized labor and protecting its ability to thrive as a private entity (i.e., protect its ability to compete). ${ }^{5}$

If telegraphy had been governed by the DORA during the war, telegraphy would be governed by perceptions of the global economy in the post-war period. If the DORA was a means of asserting the state's control over the process of telegraphy, then the international regulations asserted the British State's control over the profitability and commerciality of communications in Gibraltar. This shift was from control over infrastructure to control over profitability, or more clearly from power to profit. The British state did so through the privatization of infrastructure, much to the chagrin of Gibraltar's admiralty and colonial administrators. At its core, the privatization of telegraphy in Gibraltar is a case of global superpowers like Great Britain attempting to absorb money from the colonies, developing the superpower metropolitan's infrastructure on the material and financial backs of the colonial periphery. To the administrators and admiralty in Gibraltar, this pivot was done on their backs.

\section{Private Telegraphy, Public Inconvenience}

I am instructed to offer your company accommodation in the General Post Office, Main Street, Gibraltar at an inclusive rental of $£ 100$ per annum. The Government undertake to carry out all the necessary alterations and additions, and I forward you herewith two

\footnotetext{
${ }^{4}$ As Winseck and Pike (2007) argue, telegraph entrepreneurs rarely if ever displayed the form of jingoism projected on them by parliamentary advocates.

${ }^{5}$ Simultaneously, Marconi's wireless telegraphy company demanded that states privatize the telegraphy industry in exchange for "free" hardware installation, gaining much ground throughout Europe. There was a great deal of fear that this service, if given the chance, would buy out the whole of Europe's telecommunications and disrupt and usurp imperial communication. "The president of the [Radiotelegraphy] conference, in his opening remarks, stated that the development of radio, which was still in its infancy, would be unduly hampered by any attempt to monopolize facilities and that, therefore, rules should be made to block any attempt to impose one system upon others. His attack was made directly at the Marconi Company, and the Marconi Company's restrictive practices were cited as an example of an attempt to force one system on all the world" as cited in George Codding Jr. (1972).
} 
copies of the plan showing the nature of the proposed alterations \&c. (Gibraltar Archival Document, 1933a)

Having gutted the public service of telegraphy, Cable \& Wireless LTD existed parasitically on the back of another public system in Gibraltar: the postal service. The post office served simultaneously as competition and sacrificial offering to the privatized W. T. industry in Gibraltar. And in doing so, incensed the defenders of the colonial state in Gibraltar. Importantly, this problem was one that plagued the entirety of the British Empire. As Wireless World reported in 1918, the conflict between Marconi wireless and the Post Office was so intense that it appeared to be littered with conspiracy, affairs, spies, plots, and secret documents more the making of Jacobite conspiracies and war fantasy, than the type of catalog expected of British history (Wireless World, 1918).

In the 1930's, the postal service and savings bank existed as a paired institution in Gibraltar, with post being sent from the same counters and by the same individuals who were enlisted as bankers. This pairing started in Great Britain in 1861 by Sir Rowland Hill and William Gladstone, who saw it as a cheap way to finance public debt-particularly through war bonds in the 1920's (Kelsey, 2004). The colonial secretary's notes in August 1925 describes merchants complaining to the secretary of state of Foreign Affairs about profits garnered from the banking system by the State (Gibraltar Archival Document, n.d.). Their principle complaint: that the public debt held by the postal bank was of little to no benefit, or investment, to Gibraltar itself. The Colonial Administration's answer to this was, quite simply, to raise the postage fee to increase the funds available for Gibraltarnot redirect the spending to minimize debt. This caused further concern by the local merchants, who began advocating for a privatized postal service and against the direct and/or indirect taxations that would "reduce" their "hard earned profits". These merchants suggested that the government was devaluing the commercial opportunity through its monopoly over communication. While it would have been simple to convert and privatize telegraphy, the privatization of telegraphy in 1929 posed a threat to national security: the largely immigrant citizenry of Gibraltar would hold the capacity to send messages out of Gibraltar at a far cheaper rate with far less surveillance than they were able to send postage out of Gibraltar. The decrease in postal profits would make it near impossible to pay interest to account holders through the bank, and discourage diverse ways of reducing the danger of investing those funds and enticing savings holdings.

As the postal service began to compete against the newly privatized Cable \& Wireless, LTD for state money and support to meet its obligations, so too did the postal office begin competing for space. In 1933, Imperial and International Communications LTD-the privatized com- pany renamed-began talks to move into the post office. In a letter to the administration, the public manager of IIC LTD described the ways in which the military interferes with the work necessary of a private company, and simultaneously of the lack of space in Gibraltar to establish enough space to perform the tasks required of them by a telegraph-hungry public (Gibraltar Archival Document, 1933b). Overall, the letters between London investors, the Admiralty, and colonial secretary reflect a concern for Gibraltarians' "access" to W. T., as well as a concern that the accessibility of the postal service's greater accessibility would prove problematic for the newly privatized telegraphy company. The move of Cable and Wireless into the postal office, then, should not be understood as integration into the public economy, but rather the use of the public economy to support and develop the private enterprise of W. T., and the state's implicit preparation for divesting the public economy. ${ }^{6}$ The capitalist city council understood the steps towards divestment as a sign of the government "regulating" its monopolistic tendencies, protecting the competition distinctive of a "free market".

Cable \& Wireless LTD began working out of the postal office on 1 June 1934 (Gibraltar Archival Document, 1934a). To accommodate the company, the postal office shrank its offices, reconfigured multiple counters, and agreed on a joint managerial relationship between the government and the company workers. Two months later, the manager sent a letter requesting that a sign be placed outside the post office to mark the newly established telegraph office-which had otherwise been overlooked (Gibraltar Archival Document, 1934b).

By this time, however, governance of Gibraltar had changed so radically that approval was not just in the hands of the colonial secretary, but also an elected city council composed mostly of local business-owners (Archer, 2006). The city council approved the sign posting with no debate, enthused by the private alternatives to state services being offered.

By February 1936, the Colonial postmaster asked for a reduction in Cable \& Wireless' space, as its business had come to dominate the postal office to the point of legitimating the addition of a sign (Figure 2, Gibraltar Archival Document, 1936a). As the W. T. business expanded in 1933, the Colonial postmaster gave up his office "in the public interest". As part of the World War I effort to make government efficient, the Colonial postmaster had been given residence in the Postal Office, where he was forced to work and sleep for the time being. As space became an issue, Cable \& Wireless asked for him to give up-or move-that space too. In a letter from March 1936 , the manager of Cable $\&$ Wireless made two suggestions, based on avoiding a rewiring of the entire building for providing "adequate" telegraphic power: first, Cable and Wireless could return the upstairs southerly room for the Postmaster's quarters for a reduction of $£ 25$ per

\footnotetext{
${ }^{6}$ Private economy, here, refers to capitalists and business services outside of state ownership and regulation, while the public economy refers to those services and businesses that both provide essential services and are subsidized by the state (Zukin \& Dimaggio, 1990).
} 


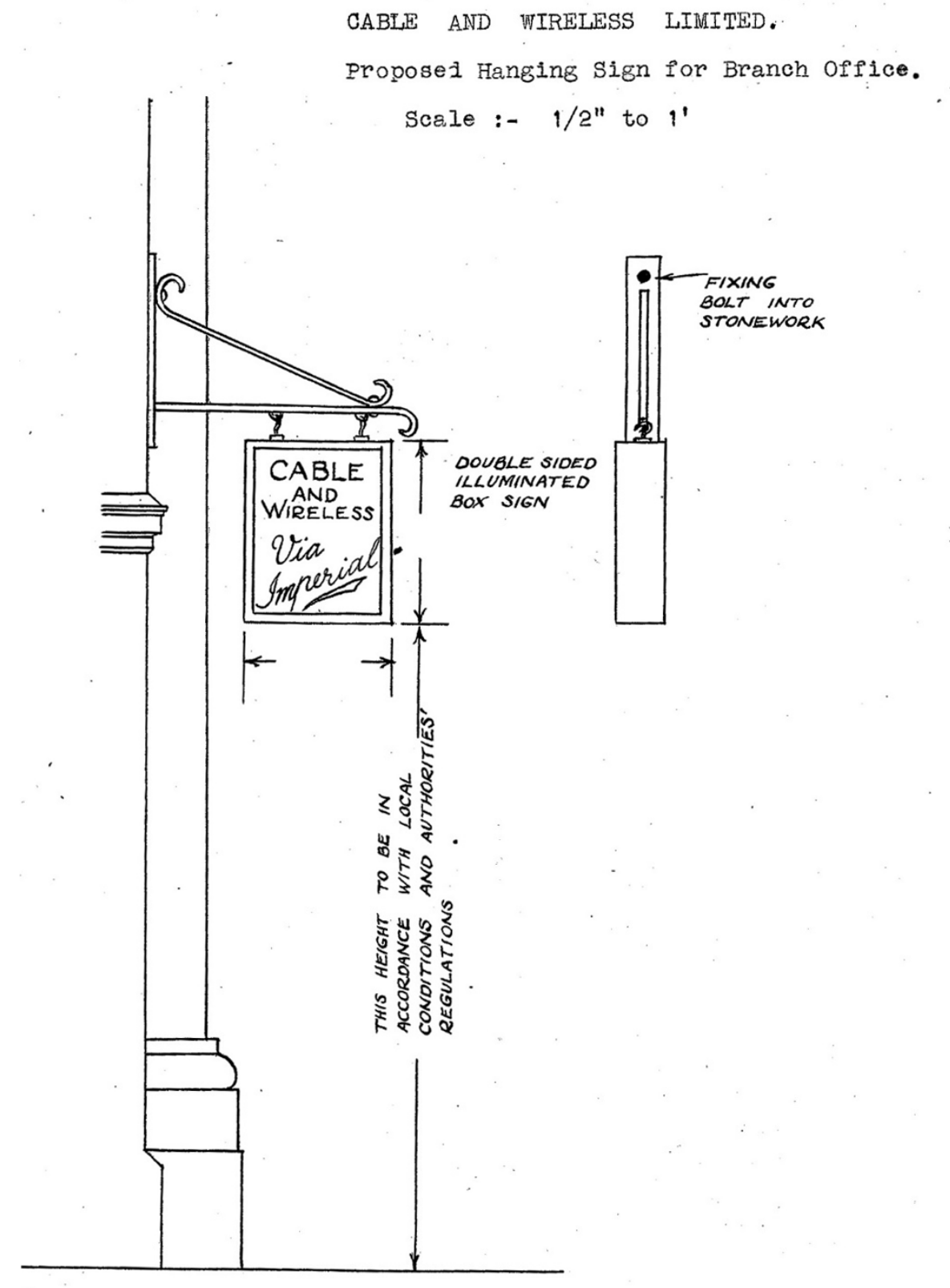

Figure 2. Proposed hanging sign for post office branch of imperial cable and wireless (1934).

annum, or give up the downstairs southerly room for a reduction of $£ 40$ per annum (Gibraltar Archival Document, 1936b). Neither, however, proved satisfactory to the postmaster general. Both rooms were plagued by both the noise of vehicles in the street and the noise of telegraphy, and that clatter was conducive to neither sleeping nor working (Gibraltar Archival Document, 1936c).

This moment marked an attempt to gain space back from privatized telegraphy industry on the part of the colonial administration-manned by aristocratic retirees of the admiralty. In a letter dated November 1940, the Colonial postmaster wrote to the Manager of Cable and Wireless. Cable and Wireless was occupying its previous location next door to the post office in addition to its postal facilities, and the post master was noti- fying him that the post office would thus reserve all counter space for parcel operations (Gibraltar Archival Document, 1940b). However, the Manager of Cable and Wireless responded promptly, sending a copy to the city council as well.

My clerical staff at present occupy part of the Anchor Line offices and not our former premises as you suggest, and, to the best of my knowledge, my company has not considered the question of vacating the General Post Office....It is hardly necessary to point out that throughout the past year our counter traffic has increased to an extent not contemplated when the move to the General Post Office was made and it seems very probable that this traffic will continue for 
some time, providing it is possible to maintain a cable office in town. (Gibraltar Archival Document, 1940c)

The colonial postmaster's frustration would only continue to grow, as would the antagonistic behavior of Cable and Wireless LTD. On December 1940, Cable and Wireless took out an advert in the Gibraltar Chronicle funneling its holiday traffic to the post office, "inviting the public to hand in telegrams to the Company Offices at the General Post Office" (Figure 3). The advertisement focused two spaces worth of customers-Cable and Wireless LTD was running another office on Barracks Road at the same time-into the small, already over-occupied space of the post office. In a letter to the manager of Cable and Wireless, dated December 1940, the Colonial postmaster responded to both the advertisement and the increased traffic.

The position today is that the Cable Company's customers are so numerous and the congestion is such that inconvenience is experienced by those having legitimate postal business to transact: e.g. Post Office customers wishing to prepare money order requisitions, Savings Bank withdraws and Parcel Post Customs Declarations find all space at the Post Office writing tables and benches occupied by Cable Company's customers engaged in the construction of telegrams; and post office customers instead of being able to avail themselves of the facilities provided by this Department for their use are obliged to fill in their forms at the public counter thereby congesting that section of the office which is reserved for public business. In these circumstances...it was agreed that the public should have reasonable access to that portion of the counter provided for the Company's uses not contemplated that the increase in the cable company's traffic would prove to be embarrassing to this administration. (Gibraltar Archival Document, 1940d)

While this struggle between private and public service was occurring, World War II began having dire effects on Gibraltar. As funding became tighter within the warloan torn British government, still reeling as it was from World War I, public infrastructure was reduced and privatized. Surely, given the antagonism between the colonial postmaster and imperial wireless manager, it was then no trouble for the Colonial postmaster to write the manager of Cable and Wireless to note the decrease in Postal Office hours instituted in response to government austerity orders. According to the Colonial postmaster, the Postal Office would open at 0900, close at mid-day, reopen at 1500 hours, and close at 1700 hours - a total of 4-5 hours of open time a day (Gibraltar Archival Document, 1940e). Incensed, the manager of Cable and Wireless responded that the decision was "detrimental to the people of Gibraltar". The demand for telegraphy services, he argued, had increased because the colonial government continued to introduce more people (troops) into Gibraltar, despite having just forced thousands of people out (evacuated Gibraltarians). Throughout the letter, he implies that "government" had lost its guiding purpose, and that it was now private business that must look after the welfare of the people-whom, for the state, are defined as citizens and for Cable and Wireless were defined as consumers. Responding to the manager's anger, the Colonial postmaster suggested that they are not closing Cable and Wireless out, that Cable and Wireless was welcome to perform tasks in the building, but that the front

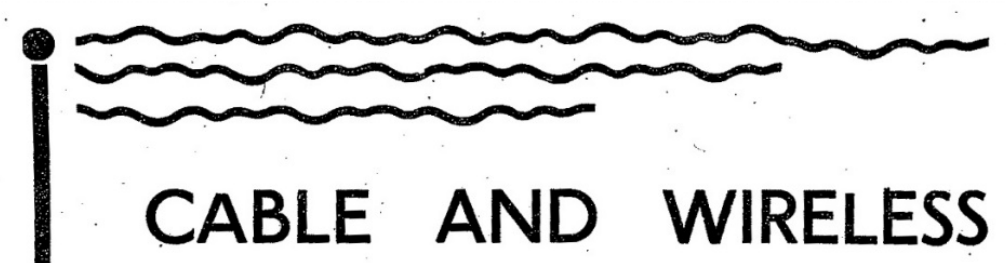

is an entirely British owned, and British operated overseas telegraph company

$\circ \circ$

There is ONLY QNE overseas telegraph company pledged to devote half its profits over a $4 \%$ dividend to further rate reductions CABLE AND WIRELESS Limited

Two very good reasons why you should roúte your message "VIA IMPERIAL."

Hand in your telegram to the Company's Offices at the General Post Office.

Figure 3. Cable \& wireless ad (16 December 1940). Source: Gibraltar Chronicle (1940, p. 3). 
doors and hall would be closed to the public during those hours. This decision, the Post Master continues, is not a restriction, but a form of austerity expected of Britons in wartime (Gibraltar Archival Document, 1941a).

The Manager's complaints did not go unheard, however. The city council, made of prominent business peoples in Gibraltar who, as described earlier, had advocated for a privatized alternative to the postal service, would vote to subsidize the expenses of Cable and Wireless maintaining hours during the closure of the Postal Office. The city council funded the installation of a grille in front of the counters of the Postal Office, so as to protect it from potential theft (Gibraltar Archival Document, 1941b). Otherwise, the hall of the postal office would remain open and available for the Company's customers.

This is not the only time the privatized service was rescued by the city council and colonial government. Between 1930 and 1940, Gibraltar received the news about the empire increasingly through telegraph. These began to include updates of Rugby scores "on the moment", as well as emergency news regarding the Empire's various military endeavors (Gibraltar Archival Document, 1939). Furthermore, individuals began purchasing private $\mathrm{W}$. T. installations to take part in experiments around the broadcast of musical performances and individual messages. This provided a great challenge to $\mathrm{Ca}$ ble and Wireless LTD's monopoly on transcontinental and colonial-metropole information exchange, particularly in Gibraltar. In March 1940, the head of the Imperial Communications Advisory Committee-a London-based committee established at the merger and privatization of all W. T. companies-sent a letter regarding both practices:

Whilst foreign countries I am unable to intervene, I do ask, in view of the recommendation of the Committee who dealt with the Empire Rate Scheme, that the countries of the Empire will prevent this invasion into the telecommunications field proper to this company by newspapers, news agencies, and other unauthorized bodies. (Gibraltar Archival Document, 1940a)

Reuters was the sole source of news on the wire. While starting independently, however, by 1940 it was fully owned by the Press Association, an organization of the provincial press of Great Britain (Crisell, 2002). In short, it was a private service that had returned to public ownership, just as telegraphy had done half a century earlier. What remains in the tone of the Manager's letter is a fear that the functions of a public company are beginning to seep into the cable business; Cable \& Wireless was expected to carry the news wire, and not given the option to refuse. Seeing a potential road to the renationalization of wireless, Cable \& Wireless turned to the government(s) of the empire, notably Gibraltar in this instance, to ask for protection against the public economy-news and information provided to citizens to imagine a nation-coming to dominate the private economy-services provided to "desiring" and "paying" consumers. In response, the colonial secretary refocused the newswire to the military W. T.; however, he did maintain private citizens' rights to own W. T. systems (Gibraltar Archival Document, 1040a). And while this was some protection from the so-called evils of nationalization at a local scale, they would be rendered moot when Cable and Wireless LTD became nationalized by the Labour Party in 1947.

\section{Conclusion: Privatization, Perspectivism, and the Coming Neoliberal Moment}

The above is not the history of telegraphy, so much as a perspective on the history of telegraphy enshrined by the Gibraltar Archives. From this perspective, W. T. in Gibraltar was the site of a complicated and shifting relationship between metropole and colony, between governor and admiralty, and between State and private enterprise. Installed initially to enable faster communication among armed forces, the perfect storm of interwar economy and crumbling empire pushed Britain to sell off Gibraltar's telegraphic infrastructure. The result was a private business that relied on the state to protect it from nationalization, recruiting domestic cabinet members in the UK to wage ideological and economic war against their lesser kinsmen that held outposts in the colony itself. The Gibraltar Archives represent the voices of an often forgotten resistance to the privatization of public communication infrastructure, namely the voice of an anti-Liberal colonial administration doing the work of managing and building Empire.

According to this archive, then, W. T. in pre-World War II Gibraltar was the site of a complicated and shifting relationships between colonial governor, admiralty, and private enterprise. Installed to enable faster communication between the armed forces of the empire, the perfect storm of a failing interwar economy and crumbling empire pushed Britain to sell off Gibraltar's telegraphic infrastructure. The result was a private business that relied on the state to protect it from nationalization, whether that nationalization was the threat of the state's "monopolistic tendencies" (Hayek, 2005), or the threat of government take over amidst declines in consumer appreciation and participation. Thus, contra a world systems theory that posits economic models coming from the core and exported to the periphery, I am arguing that the neoliberal mode of production was a material condition formulated in the colony before returning to the metropole as a systemic relationship facilitated through privatization-long before it was a formulated economic rationality to be deployed in that very metropole. This argument is not to suggest that Gibraltar was the birthplace of neoliberalism; but rather, that what is narrated as a post-World War II political economic rationality in Europe has deeply set imperial roots as part of a long, colonial history of neoliberal transformation.

Opening that argument out to the present, it becomes clear that the contemporary neoliberal moment- 
wrapped as it is in struggles over the privatization of public infrastructure-did not spring forth from Athena-like from the post-1968 world. Rather, neoliberalism is the colonial formation of a type of capitalism that, at very least, played out in the telegraphy economy of Gibraltar (and undoubtedly in countless other places), hidden in the strata of world history. Whether we're speaking of Atlee's and then Thatcher's British government, or the policy and institution shifts in the US driven by Lewis Powell's 1971 US Chamber of Commerce memo or the policies put into place by Ronald Raegan's administration (Harvey, 2007), each pulled its models for economic change from the modes of production that made the pivot from colonialism to imperialism possible.

\section{Acknowledgements}

I am very grateful to my colleagues at the Gibraltar Museum, Institute for Gibraltar Studies, and the Gibraltar Archives who made this research possible. I would also like to thank Dr. Janet Wasko and Dr. Elizabeth Patton for their thoughtful comments on early and later drafts of this article, as well my colleagues from the Social Science Research Council Mediated Future cohort and the department of media and communication studies at the University of Maryland, Baltimore County. Finally, I am indebted to the careful work of the editors and peer reviewers, who provided a great deal of direction for this final draft.

\section{Conflict of Interests}

The author declares no conflict of interests.

\section{References}

Archer, E. (2006). Gibraltar, identity, and empire. New York, NY: Routledge.

Barty-King, H. (1980). Girdle round the Earth: History of "cable and wireless". London: William Heinemann Ltd.

Broadberry, S., \& Harrison, M. (Eds.). (2009). The economics of World War I (1st ed.). Cambridge: Cambridge University Press.

Caruana, L., Rockoff, H., \& National Bureau of Economic Research. (2006). An elephant in the garden: The allies, Spain, and oil in World War II (NBER Working Paper No. 12228). Retrieved from http:// papers.nber.org/papers/w12228

Crisell, A. (2002). An introductory history of British broadcasting (2nd ed.). London: Routledge.

Defence of the Realm Act. (1914). Defence of the Realm manual (6th ed.). Washington, DC: Library of Congress.

Dirks, N. (2002). Annals of the archive: Ethnographic notes on the sources of history. In B. K. Axel (Ed.), From the margins: Historical anthropology and its futures (pp. 47-65). Durham, NC: Duke University Press.
Finlayson, T. J. (1996). The fortress came first: The story of the civilian population of Gibraltar during the Second World War. London: Ashford, Buchan, and Enright.

Gibraltar Archival Document (n.d.). Colonial secretary's notes. Gibraltar Archives (Box 1924, Folder 136).

Gibraltar Archival Document. (1914c). 30/12/1914 Correspondence. Gibraltar Archives (Box 1922, Folder 500).

Gibraltar Archival Document. (1915a). 16/6/15 Correspondence. Gibraltar Archives (Box 1922, Folder 500).

Gibraltar Archival Document. (1915b). 29/10/15 Correspondence. Gibraltar Archives (Box 1922, Folder 500).

Gibraltar Archival Document. (1915c). 12/12/15 Correspondence. Gibraltar Archives (Box 1922, Folder 500).

Gibraltar Archival Document. (1922a). 12/7/22 Telegraph. Gibraltar Archives (Box 1922, Folder 500).

Gibraltar Archival Document. (1922b). 2/9/1922 Telegram \& Circular from Winston Churchill. Gibraltar Archives (Box 1922, Folder 254).

Gibraltar Archival Document. (1922c). 6/10/22 Correspondence. Gibraltar Archives (Box 1922, Folder 500).

Gibraltar Archival Document. (1922d). 12/10/22 Correspondence. Gibraltar Archives (Box 1922, Folder 500).

Gibraltar Archival Document. (1924). 29/9/24 Committee Circular. Gibraltar Archives (Box 1924, Folder 23).

Gibraltar Archival Document. (1925). 26/8/25 Correspondence. Gibraltar Archives (Box 1924, Folder 19).

Gibraltar Archival Document. (1929a). [prepared by Treasury Solicitor]. Agreement relating to the Imperial Cable and Wireless Systems, between His Majesty the King, Cable and Wireless LTD, and Imperial \& International Communications LTD- 29 May 1929. Gibraltar Archives (Box 1928, Folder 374).

Gibraltar Archival Document. (1929b). 27/8/29 Correspondence. Gibraltar Archives (Box 1929, Folder 374).

Gibraltar Archival Document. (1929c). 9/9/29 Correspondence. Gibraltar Archives (Box 1929, Folder 129).

Gibraltar Archival Document. (1930a). 4/12/30 Correspondence. Gibraltar Archives (Box 1929, Folder 129).

Gibraltar Archival Document. (1930b). Precis composed by colonial secretary, documenting September 1914 to July 1922. Gibraltar Archives (Box 1930, Folder Unnumbered)

Gibraltar Archival Document. (1933a). 26/10/33 Correspondence from Crown Engineer to Manager of Imperial and International Communications LTD. Gibraltar Archives (Box 1933, Folder 257).

Gibraltar Archival Document. (1933b). Precis of Correspondence. Gibraltar Archives (Box 1933, Folder 257).

Gibraltar Archival Document. (1934a). 1/6/34 Correspon- 
dence. Gibraltar Archives (Box 1933, Folder 257).

Gibraltar Archival Document. (1934b). 9/8/34 Correspondence. Gibraltar Archives (Box 1933, Folder 257).

Gibraltar Archival Document. (1934c). 1/10/34 Correspondence. Gibraltar Archives (Box 1929, Folder 129).

Gibraltar Archival Document. (1936a). 13/2/36 Correspondence. Gibraltar Archives (Box 1933, Folder 257).

Gibraltar Archival Document. (1936b). 27/3/36 Correspondence. Gibraltar Archives (Box 1933, Folder 257).

Gibraltar Archival Document. (1936c). 27/3/36 Correspondence. Gibraltar Archives (Box 1933, Folder 257).

Gibraltar Archival Document. (1939). Announcement from Downing Street. Gibraltar Archives (Box 1921, Folder 467).

Gibraltar Archival Document (1940a). 5/3/40 Announcement from Communications Advisory Committee. Gibraltar Archives: Box 1922, Folder 473.

Gibraltar Archival Document. (1940b). 20/11/40 Correspondence. Gibraltar Archives (Box 1933, Folder 257).

Gibraltar Archival Document. (1940c). 26/11/40 Correspondence. Gibraltar Archives (Box 1933, Folder 257).

Gibraltar Archival Document. (1940d). 18/12/1940 Correspondence. Gibraltar Archives (Box 1933, Folder 257).

Gibraltar Archival Document. (1940e). 27/12/40 Correspondence. Gibraltar Archives (Box 1933, Folder 257).

Gibraltar Archival Document. (1941a). 1/1/41 Correspon- dence. Gibraltar Archives (Box 1933, Folder 257).

Gibraltar Archival Document. (1941b). 8/8/41 Correspondence. Gibraltar Archives (Box 1933, Folder 257).

Gibraltar Chronicle. (1940) Imperial Wireless Advertisement. Gibraltar Chronicle, p. 3.

Hayek, F. A. v. (2005). The road to serfdom: With, the intellectuals and socialism. London: Institute of Economic Affairs.

Harvey, D. (2007). A brief history of neoliberalism. New York, NY: Oxford University Press.

Kelsey, D. M. (2004). Life and public services of Honorable William E. Gladstone containing a full account of the most celebrated orator and statesman of modern times. Whitefish, MT: Kessinger Publishing, LLC.

Landes, D. S. (1969). The unbound Prometheus: Technological change and industrial development in Western Europe from 1750 to the present. London: Cambridge University Press.

Porter, B. (2006). The absent-minded imperialists: Empire, society, and culture in Britain (1st ed.). Oxford and New York, NY: Oxford University Press.

Robbins, K. (1996). A bibliography of British history, 1914-1984 (Vols. 1-6). London: Clarendon Press.

Startt, J. D., \& Sloan, W. D. (1989). Historical methods in mass communication. Hillsdale, NJ: L. Erlbaum Associates.

Winseck, D. R., \& Pike, R. M. (2007). Communication and empire: Media, markets, and globalization, 18601930. Durham, NC: Duke University Press.

Wireless Word. (1918, June). Imperial wireless chain litigation. Wireless World, pp. 113-114.

Zukin, S., \& Dimaggio, P. (1990). Structures of capital: The social organization of the economy. Cambridge: Cambridge University Press.

\section{About the Author}

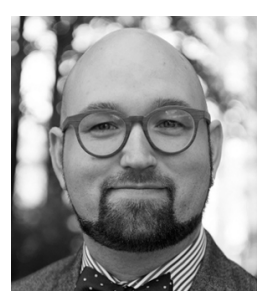

Bryce Peake is an assistant professor of Media and Communication Studies at the University of Maryland, Baltimore County. His research examines the relationship between media technologies, science, and the body in the post-World War II British and American empires. His first book Media Citizens: Standpoint Acostemology and the Media Sciences that Made Gibraltarian Men British is currently under review, and he is now working on an historical, big data ethnography of listening in American and British conspiracy communities. 